\title{
Disease and nutrient enrichment as potential stressors on the Caribbean sponge Aplysina cauliformis and its bacterial symbionts
}

\author{
D. J. Gochfeld ${ }^{1,2, *}$, C. G. Easson ${ }^{2}$, C. J. Freeman ${ }^{3}$, R. W. Thacker ${ }^{3}$, J. B. Olson ${ }^{4}$ \\ ${ }^{1}$ National Center for Natural Products Research and ${ }^{2}$ Environmental Toxicology Research Program, \\ University of Mississippi, University, Mississippi 38677-1848, USA \\ ${ }^{3}$ Department of Biology, University of Alabama at Birmingham, Birmingham, Alabama 35294, USA \\ ${ }^{4}$ Department of Biological Sciences, University of Alabama, Tuscaloosa, Alabama 35487, USA
}

\begin{abstract}
Sponge diseases have recently emerged as potential forces structuring coral reefs. The increasing prevalence of disease on reefs may be due to changes in the virulence of pathogens and/or to decreases in host resistance as a result of changing environmental conditions. Coral reef ecosystems typically thrive in oligotrophic waters; however, runoff of fertilizers or sewage that contains elevated concentrations of nutrients can lead to eutrophic conditions. Aplysina cauliformis is a dominant member of the Caribbean sponge community, and is susceptible to Aplysina Red Band Syndrome (ARBS), a disease that causes reduced sponge growth and survival. We assessed the independent and interacting effects of nutrient enrichment and disease on A. cauliformis, using a factorial field experiment in which healthy and diseased sponges were exposed to nutrient-enriched or non-enriched treatments. Impacts on ARBS virulence (rate of lesion growth) and host response (both sponge and cyanobacterial symbiont growth and physiology) were assessed. ARBS lesions increased rapidly regardless of nutrient treatment, and disease had a significantly greater detrimental impact on sponges than did nutrient enrichment, as evidenced by a decline in sponge mass and reduced total protein content. The sponge-cyanobacterial symbiont relationship was less impacted by disease, although the sponge-associated bacterial community was significantly affected by sponge condition, with healthy sponges and diseased tissue hosting significantly different bacterial assemblages. In contrast, nutrient enrichment had no effects on sponge or symbiont physiology. Disease is a much greater stressor than eutrophication on the growth and physiology of A. cauliformis and its cyanobacterial symbionts.
\end{abstract}

KEY WORDS: Sponge disease $\cdot$ Nutrient enrichment $\cdot$ Symbiosis $\cdot$ Stressors

\section{INTRODUCTION}

Coral reef ecosystems face increasing threats from a combination of natural and anthropogenic impacts, including pathogenesis, global climate change, and local disturbances that affect overall water quality (Rosenberg \& Loya 2004, Fabricius 2005, HoeghGuldberg et al. 2007, Carpenter et al. 2008). Coastal development has intensified dramatically in recent decades, generating increased sedimentation and turbidity, as well as elevated concentrations of inorganic nutrients, particularly those derived from fertilizers and insufficiently treated sewage (Fabricius 2005). Increasing eutrophication of coastal waters has contributed to dramatic phase shifts from coraldominated to macroalgal-dominated reefs over the past several decades (Lapointe 1997, McCook 1999), even though the relative strengths of top-down versus bottom-up factors in coral reef phase shifts remain controversial (Szmant 2002). 
Diseases of marine invertebrates have received increasing attention recently, as infectious diseases of the sea urchin Diadema antillarum and scleractinian corals are considered to be major causes of the accelerating destruction of Caribbean coral reef ecosystems (Hughes 1994, Porter et al. 2001, Aronson et al. 2004, Rosenberg \& Loya 2004). The best described marine diseases are those of hard corals, and new coral diseases have been reported with increasing frequency in an expanding number of hosts on a global scale (Rosenberg \& Loya 2004, Ward \& Lafferty 2004, Raymundo et al. 2008). Diseases of sponges were documented as early as the 1940s, when disease ravaged the commercial sponge industry in the Caribbean (Galtsoff et al. 1939, Smith 1941). Sponge diseases have recently been rediscovered across the globe (Rützler 1988, Gaino et al. 1992, Vacelet et al. 1994, Webster et al. 2002, Cervino et al. 2006, Cowart et al. 2006, Olson et al. 2006, Wulff 2006, 2007, Webster 2007, Maldonado et al. 2010).

Nutrient enrichment is hypothesized to contribute to the onset and severity of coral diseases by elevating microbial growth rates, enhancing virulence of pathogens, and promoting blooms of algae or cyanobacteria (Glibert et al. 2004, Rodier \& Le Borgne 2008). Correlative studies suggest that increased concentrations of nutrients are associated with increased prevalence of various coral diseases, including Black Band Disease (Kuta \& Richardson 2002, Kaczmarsky et al. 2005), White Plague type II (Kaczmarsky et al. 2005), Porites Ulcerative White Spots, and Porites growth anomalies (Kaczmarsky \& Richardson 2011). In experimental nutrient exposures, Black Band Disease (Voss \& Richardson 2006), aspergillosis, and Yellow Band Disease (Bruno et al. 2003) exhibited increased virulence with increased nutrient dose, as measured by rate of disease progression.

Sponges are represented by enormous structural, functional, and taxonomic diversity (Diaz \& Rützler 2001, Rützler 2004, Bell 2008) and provide critical ecosystem services, including essential habitat and structure, consolidation of reef structures, food for predators, and removal of particulate matter from the water column. Like corals, some of the success of coral reef sponges comes from their photosymbiosis, typically with cyanobacteria, that provides some sponge hosts with significant inputs of carbon and nitrogen (Erwin \& Thacker 2008, Freeman \& Thacker 2011) and contributes to nutrient cycling (Fiore et al. 2010).

One of the dominant sponges on shallow Caribbean reefs is the branching sponge Aplysina cauli- formis. Healthy individuals of this species harbor dense populations of the unicellular cyanobacterium Synechococcus spongiarum and a diverse community of bacterial associates (Erwin \& Thacker 2007, Hardoim et al. 2009); these microbial symbionts contribute photosynthates to host sponge metabolism (Freeman \& Thacker 2011). A. cauliformis is affected by Aplysina Red Band Syndrome (ARBS), which manifests as a red band that progresses along the branch of the sponge, leaving behind necrotic tissue that becomes colonized by algae (Olson et al. 2006). The red band is comprised primarily of red filamentous cyanobacteria (Olson et al. 2006), but the etiologic agent of this disease has not yet been identified. Although widely distributed throughout the greater Caribbean region, ARBS is particularly common in the Exuma Cays, Bahamas, where up to $15 \%$ of $A$. cauliformis are affected (Olson et al. 2006). Gochfeld et al. (2007) suggested that population densities of this sponge can serve as indicators of environmental conditions. For example, in Bocas del Toro, Panama, ARBS prevalence was greatest at the site impacted by elevated nutrient concentrations and polycyclic aromatic hydrocarbons, even though Aplysina sponges were rare at that site (Gochfeld et al. 2007).

Over the past several years, we have observed formerly uninhabited regions of the Bahamian islands undergoing accelerating coastal development, increasing the exposure of previously pristine ecosystems to land-based stressors. Due to its abundance, its potential use as a bioindicator species, and its susceptibility to ARBS, we used Aplysina cauliformis as a model to study the impacts of elevated nutrient concentrations on ARBS progression. To test the effects of nutrient enrichment on healthy and ARBS-affected A. cauliformis, we conducted a factorial field experiment. This enabled us to evaluate the effects of disease and nutrient enrichment, independently and together, on ARBS virulence, sponge condition, symbioses between sponges and their cyanobacterial symbionts, and sponge-associated microbial communities.

\section{MATERIALS AND METHODS}

\section{Study site and species}

This study was conducted at the Caribbean Marine Research Center/Perry Institute for Marine Science on Lee Stocking Island (LSI), Exuma Cays, Bahamas, from 11 June to 9 July 2009. The Exuma Cays are relatively pristine by most Caribbean standards, and 
LSI is over $40 \mathrm{~km}$ from the nearest major town. However, the study site is located $\sim 3.5 \mathrm{~km}$ from a small cay where a private resort with a golf course is under construction.

Aplysina cauliformis is common on shallow reefs in the Bahamas. Samples of healthy and diseased A. cauliformis (thin branching morph) were collected at North Norman's reef $\left(23^{\circ} 47.388^{\prime} N, 76^{\circ} 08.273^{\prime} \mathrm{W}\right)$ from a depth of $5 \mathrm{~m}$, and the experiment was deployed $0.3 \mathrm{~km}$ to the south at Big Point $\left(23^{\circ} 47.301^{\prime} \mathrm{N}, 76^{\circ} 08.118^{\prime} \mathrm{W}\right)$, at the same depth.

\section{Field nutrient experiment}

To assess the relative impacts of disease and nutrient enrichment on the health of Aplysina cauliformis and its cyanobacterial symbionts, we performed a factorial field experiment in which healthy and diseased sponges were exposed to ambient (control) or nutrient-enriched conditions $(\mathrm{n}=12$ in each treatment), modifying experimental methods previously reported by Freeman \& Thacker (2011). Fragments $(20 \mathrm{~cm})$ of sponges from North Norman's reef were collected into individual resealable plastic bags and transported to the wet lab on LSI, where they were maintained overnight. Healthy sponges were placed in a separate water table from diseased sponges. From each individual, initial samples were collected for analysis of total protein concentration, cyanobacterial symbiont density, chlorophyll a (chl a) concentration, and bacterial community composition. Sponges were cut to $10 \mathrm{~cm}$, photographed, weighed, and measured. All sponges were cut on both ends, so any potential stress resulting from the cutting should be similar in all sponges. Stress due to cutting was considered minimal, as new sponge tissue was noted at these cut ends by the end of the first week. After dark on the day of collection, pulse-amplitude modulated fluorometry (PAM) measurements were made on dark-adapted sponges using a Diving-PAM (see below). Sponges were then attached to $20 \times 20 \mathrm{~cm}$ plastic racks using plastic cable-ties, at a distance of $5 \mathrm{~cm}$ on either side of a nutrient pack wrapped in window screen (Thacker et al. 2001) or a window screen control pack (empty). Each rack contained 2 sponges from the same treatment group. The nutrient pack contained $10 \mathrm{~g}$ of Osmocote ${ }^{\circledR}$ slow-release fertilizer (14-14-14 N-P-K), and both nutrient packs and empty control packs were replaced weekly for the 4 wk duration of the experiment. Within $24 \mathrm{~h}$ of sponge collection, racks were attached at a depth of $5 \mathrm{~m}$ on the reef at Big Point. All racks were placed parallel to the reef, with a minimum distance of $5 \mathrm{~m}$ between racks. Water samples were collected in $250 \mathrm{ml}$ Nalgene bottles immediately over 1 sponge on 3 control and 3 nutrient racks prior to nutrient pack deployment (Day 0) and on Days 1 and 7, to assess the degree of nutrient enrichment to which the sponges were exposed. Samples were filtered through a $0.2 \mu \mathrm{m}$ filter and frozen for transport to the Woods Hole Oceanographic Institute (Woods Hole, Massachusetts, USA). Nitrate (+nitrite) measurements were performed using the Lachat QuickChem Method 31-107-04-1-E (Wood et al. 1967). Phosphate measurements were performed using the Lachat QuickChem Method 31-115-01-1-H (Murphy \& Riley 1962). The limit of detection for both of these methods was $0.05 \mu \mathrm{M}$.

At the end of the experiment, racks were placed in resealable plastic bags underwater and transported to the wet lab at LSI, where they were maintained over night. After dark on the day of collection, PAM measurements were recorded. The following day, sponges were removed from the racks, photographed, weighed, and measured. Small pieces (5 $\mathrm{mm}$ thick cross-sections) of healthy tissue from each sponge were collected for total protein concentration, cyanobacterial symbiont density, chl a concentration, and bacterial community analysis. Small pieces of the active red band were also collected for bacterial community composition. Samples were preserved or frozen until analyzed, as described below.

\section{Analytical methods}

Lesion growth and development. Measurements of the length of healthy tissue, red bands, and necrotic portions of lesions on each diseased sponge were made initially and at the conclusion of the experiment. In all cases, measurements in a shallow basin of seawater were made with a ruler on the side of the sponge where the lesion was largest. In addition, photographs of the sponge were taken from all sides for comparison of changes in lesion development or appearance of new lesions.

Sponge growth. Sponge weights were determined initially and at the conclusion of the experiment. Sponges were briefly blotted with a paper towel to remove excess water prior to weighing. Time spent out of water was minimal. The relative percent change in sponge weight was calculated using the equation: ([final weight - initial weight]/initial weight) $\times 100$. 
Total protein concentration. Soluble protein content was measured as an indicator of sponge tissue condition, using the Bradford assay (Bradford 1976). Briefly, $10 \mathrm{mg}$ of lyophilized sponge tissue was extracted in $5 \mathrm{ml}$ of $1 \mathrm{M}$ sodium hydroxide for $18 \mathrm{~h}$. After extraction, $100 \mu \mathrm{l}$ of extract were mixed with $5 \mathrm{ml}$ of Quick Start ${ }^{\mathrm{TM}}$ Bradford Dye Reagent (Bio-Rad). Absorbance of each sample was quantified at $595 \mathrm{~nm}$ and plotted against a standard curve using bovine serum albumin to determine $\mu \mathrm{g}$ protein $\mathrm{mg}^{-1}$ sponge tissue.

Cyanobacterial symbiont densities. The abundance of cyanobacteria in sponge tissue was quantified using a histology-based metric (Freeman \& Thacker 2011). Cross-sections of the sponges were placed into $2 \mathrm{ml}$ cryovials with $4 \%$ paraformaldehyde solution and stored at $4{ }^{\circ} \mathrm{C}$ for $24 \mathrm{~h}$, after which this solution was replaced with $70 \%$ ethanol. Cyanobacterial cell abundance was quantified using paraformaldehyde-fixed samples that were dehydrated, embedded in paraffin wax, cut into $20 \mu \mathrm{m}$ sections, and mounted onto glass slides. These sections were viewed under oil at $1000 \times$ using an epifluorescence microscope. For each sample, 10 photographs were taken from haphazardly chosen regions of a section. The number of cyanobacterial cells was counted in each picture using the 'analyze particles' feature of Image-J. Total cell number in each field of view was averaged to obtain a mean number of cells per viewing area $\left(2886 \mu \mathrm{m}^{2}\right)$.

Chlorophyll a concentration. We also used chl a as a metric for cyanobacterial symbiont abundance. Chl a was measured using the methods of Erwin \& Thacker (2007), except that sponges were lyophilized prior to extraction. We extracted $0.25 \mathrm{~g}$ wet weight of Aplysina cauliformis in $10 \mathrm{ml}$ of $90 \%$ acetone in the dark for $18 \mathrm{~h}$ at $4^{\circ} \mathrm{C}$. The absorbance of each extract was quantified at 750,664, 647, and $630 \mathrm{~nm}$ using an Agilent 8453 spectrophotometer. Estimations of chl a concentrations were calculated as $\mu \mathrm{g} \mathrm{mg}{ }^{-1}$ sponge tissue, using formulas from Parsons et al. (1984), standardized to the mass of the extracted sponge.

Fluorescent yield. Photosynthetic efficiency of the photosymbionts within the host sponge tissue was estimated from chlorophyll fluorescence measurements taken with a PAM fluorometer (DIVING-PAM, Walz). Measurements were made at 3 locations on each sponge by placing a fiber optic probe at a standard distance and angle from the sponge. Measurements were made 1 to $1.5 \mathrm{~h}$ after sunset to obtain maximum potential quantum yield $\left(F_{\mathrm{v}} / F_{\mathrm{m}}\right.$, where $F_{\mathrm{v}}=$ minimum fluorescence $\left[F_{0}\right]-$ maximum fluorescence $\left.\left[F_{\mathrm{m}}\right]\right)$ of dark-adapted symbionts. PAM readings were made on the night prior to deployment in the field and on the night following collection from the field at the conclusion of the experiment. For diseased sponges, only the healthy tissue was sampled.

Microbial community profiles. Total DNA was extracted from small pieces of sponge tissue from a subset of healthy sponges $(n=5)$, and both ARBSaffected $(\mathrm{n}=5)$ and visibly healthy $(\mathrm{n}=5)$ tissue on ARBS-affected sponges, for both nutrient-enriched and control individuals using the FastDNA® Spin Kit for Soil (Qbiogene). For terminal restriction fragment length polymorphism (T-RFLP) analyses, small subunit rRNA genes were amplified by polymerase chain reaction (PCR) using the universal bacterial primers $8 \mathrm{~F}$ with a fluorescent $S$-hexachlorofluorescein (HEX) label (5'-AGA GTT TGA TCM TGG CTC AG-3') and 1392R (5'-ACG GGC GGT GTG TAC A-3'). Each $50 \mu \mathrm{l}$ PCR mixture contained 50 to $100 \mathrm{ng}$ of template DNA, 2 U MasterTaq DNA polymerase (5 Prime), 1× Taq buffer (5 Prime), $2.75 \mu \mathrm{M}$ $\mathrm{Mg}(\mathrm{O} \text {-acetate })_{2}, 1 \times$ Taq Master PCR Enhancer (5 Prime), each deoxynucleoside triphosphate at a concentration of $20 \mu \mathrm{M}$, and each primer at a concentration of $0.4 \mu \mathrm{M}$. The PCR conditions were $85^{\circ} \mathrm{C}$ for $5 \mathrm{~min}, 30$ cycles of $94^{\circ} \mathrm{C}$ for $45 \mathrm{~s}, 55^{\circ} \mathrm{C}$ for $1 \mathrm{~min}$, and $72^{\circ} \mathrm{C}$ for $90 \mathrm{~s}$, and a final $7 \mathrm{~min}$ extension at $72^{\circ} \mathrm{C}$. Triplicate $50 \mu \mathrm{l}$ PCR products were individually cleaned using QIAquick PCR purification columns (Qiagen), pooled, and the amount of DNA was quantified using a NanoDrop 2000 spectrophotometer (Thermo Scientific).

Digests were conducted individually using HaeIII and HhaI restriction endonucleases (New England Biolabs). Reactions were carried out using $400 \mathrm{ng}$ cleaned PCR products, 1× enzyme buffer (New England Biolabs), $2 \mathrm{U}$ of restriction endonuclease, and sterile distilled $\mathrm{H}_{2} \mathrm{O}$ to a total volume of $50 \mu \mathrm{l}$. Reaction mixtures were incubated at $37^{\circ} \mathrm{C}$ for $8 \mathrm{~h}$ prior to denaturing the endonuclease and stored at $4^{\circ} \mathrm{C}$. DNA was ethanol-precipitated overnight and centrifuged, and the pellet was dried using a Centrivac. Pellets were resuspended in $10 \mu \mathrm{l}$ of deionized formamide and $0.5 \mu$ 6-carboxytetramethylrhodamine size standard prior to being analyzed with an ABI 3100 genetic analyzer with a $50 \mathrm{~cm}$ capillary array (Applied Biosystems). Fragment lengths were determined using the Local Southern size-calling algorithm of the Genemapper analysis software version 3.7 (Applied Biosystems).

Data matrices were constructed using peaks above a threshold of 50 fluorescence units, which was considered to be the background level. Peaks smaller than $100 \mathrm{bp}$ and greater than $500 \mathrm{bp}$ were removed from the data set to avoid uncertainties associated 
with fragment size determination. The variable threshold method proposed by Osborne et al. (2006) was used to determine which peaks were analyzed. These data were normalized to the total fluorescence units per sample and analyzed in T-REX (Culman et al. 2009).

Data analysis. Length of the bands, necrotic tissue, and healthy tissue in diseased sponges were analyzed using analysis of variance (ANOVA) with nutrient dose and time as main factors and rack as a blocking factor. Percent change in sponge weight was arcsine transformed and analyzed using an ANOVA with sponge condition and nutrient dose as the main factors and rack as a blocking factor. Total protein concentration, cyanobacterial symbiont density, chl a concentration, and dark-adapted fluorescent yield were analyzed using ANOVA with sponge condition, nutrient dose, and time as the main factors and rack as a blocking factor. The relationship between chl a concentration and cyanobacterial symbiont density was analyzed using regression analysis.

To compare microbial communities among treatments, Bray-Curtis similarity matrices were constructed using PRIMER 6.0 software (University of Plymouth), with fourth root transformations of the distance matrices calculated from T-REX estimates of peak area. Nonmetric, multidimensional scaling (MDS) plots were used to visualize differences in the T-RFLP profiles. One-way and 2-way analyses of similarity (ANOSIM) were used for statistical comparisons between treatments (PRIMER 6.0).

\section{RESULTS}

\section{Nutrient measurements}

Ambient concentrations of nitrates and phosphates were near or below detection limits on the control racks throughout the experiment, ranging from $\leq 0.05$ to $0.07 \mu \mathrm{M}$ for nitrate and $\leq 0.5 \mu \mathrm{M}$ for phosphate. On the nutrient racks, enrichment occurred throughout the experiment. Initial (Day 0) nutrient concentrations were $\leq 0.05 \mu \mathrm{M}$ for both nitrate and phosphate on the nutrient racks. At the distance of the sponges from the fertilizer packs $(5 \mathrm{~cm})$, nitrate concentrations were enriched at least 4.4 -fold $(0.05 \pm 0 \mu \mathrm{M}$ versus $0.22 \pm 0.11 \mu \mathrm{M} \mathrm{NO}_{3}$, mean $\pm \mathrm{SE}$ ) after $1 \mathrm{~d}$, and at least 4.8 -fold $(0.05 \pm 0 \mu \mathrm{M}$ versus $0.24 \pm 0.08 \mu \mathrm{M}$ $\mathrm{NO}_{3}$ ) after $7 \mathrm{~d}$ of fertilizer deployment. Phosphate concentrations were enriched at least 2.1-fold $(0.05 \pm$ $0 \mu \mathrm{M}$ versus $0.11 \pm 0.04 \mu \mathrm{M} \mathrm{PO}_{4}$ ) on Day 1 , although they returned to ambient concentrations by Day 7 .

\section{Lesion growth and development}

ARBS lesions increased substantially in size over the course of the experiment (Fig. 1a,b). Nutrient enrichment had no significant effect on the growth of bands (ANOVA, $\mathrm{p}=0.94$ ) or necrotic tissue (ANOVA, $\mathrm{p}=0.12)$, or in the reduction of healthy tissue (ANOVA, p = 0.14) (Fig. 1c). Red bands and necrotic tissue on diseased sponges increased significantly in size (bands: $0.87 \pm 0.42 \mathrm{~cm}$ initially versus $1.64 \pm$
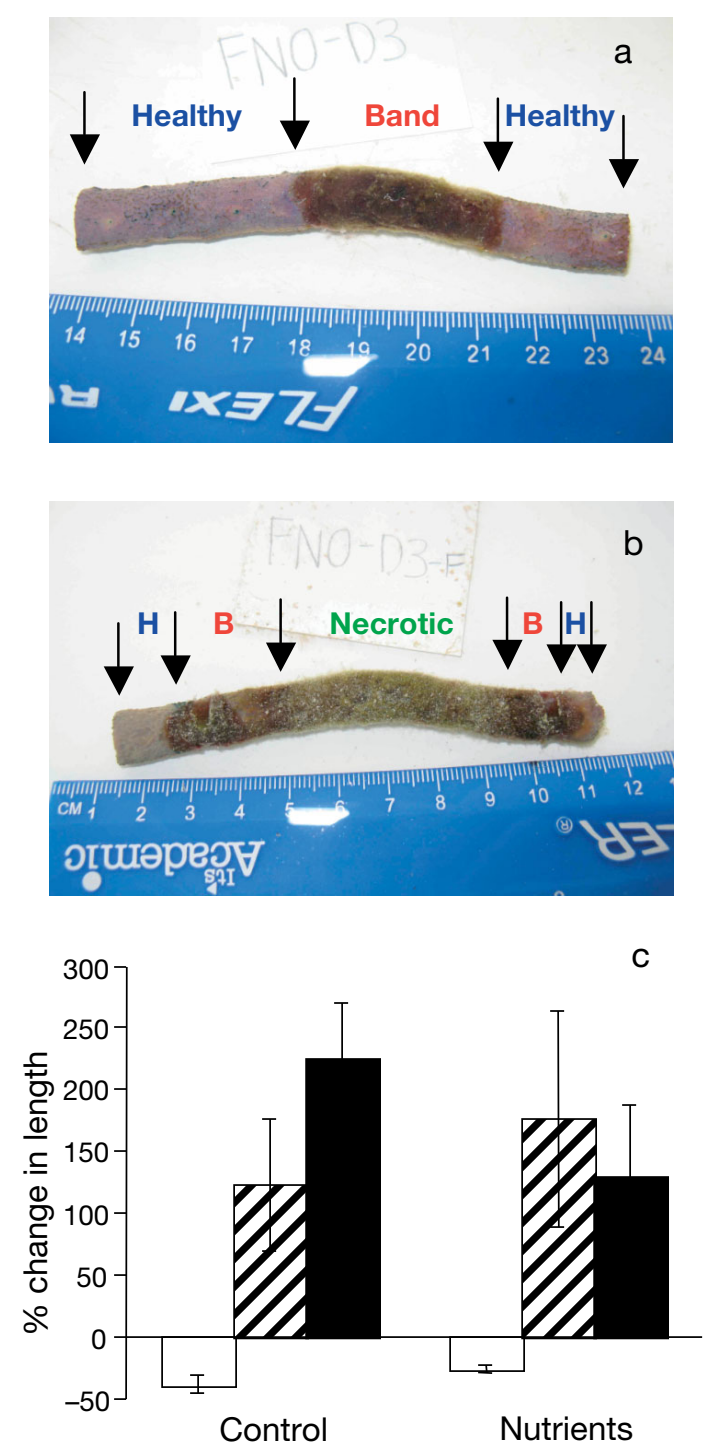

Fig. 1. Aplysina cauliformis. Representative specimen affected by Aplysina Red Band Syndrome (ARBS) (a) initially, and (b) finally, showing the expansion of the lesion along the sponge. (c) Percent change (mean \pm SE) in length of healthy tissue (open bars), red bands (hatched bars), and necrotic tissue (solid bars) on control $(\mathrm{n}=12)$ and nutrientenriched $(\mathrm{n}=12)$ A. cauliformis affected by ARBS. H: healthy; B: band 
$1.55 \mathrm{~cm}$ finally; ANOVA, $\mathrm{p}=0.015$ for time; necrotic tissue: $0.99 \pm 0.70 \mathrm{~cm}$ initially versus $2.89 \pm 3.87 \mathrm{~cm}$ finally; ANOVA, p < 0.001 for time), and healthy tissue on diseased sponges decreased significantly $(8.08 \pm 0.89 \mathrm{~cm}$ initially versus $5.49+3.18 \mathrm{~cm}$ finally; ANOVA, $p<0.001$ for time) both in the presence and absence of exogenous nutrients (Fig. 1c). There were no significant effects of rack on any of these measures. Six diseased sponges developed a second lesion; however, 3 of these were controls and 3 were in the nutrient treatment.

\section{Sponge growth}

Overall, healthy sponges increased in weight by $8.65 \pm 1.45 \%$ while diseased sponges lost $6.04 \pm$ $3.02 \%$ of their weight during the experiment (ANOVA, $\mathrm{p}<0.001$ ). Sponge growth was not significantly affected by nutrient dose (ANOVA, $\mathrm{p}=0.31$ ). Healthy sponges increased in weight by $0.45 \pm 0.15 \mathrm{~g}$ for controls and $0.8 \pm 0.11 \mathrm{~g}$ in the nutrient treatment, whereas diseased sponges decreased in weight by $0.66 \pm 0.43 \mathrm{~g}$ in controls and $0.4+0.27 \mathrm{~g}$ in the nutrient treatment. The interaction between sponge condition and nutrient dose was not significant, and there was no significant effect of rack on sponge growth (ANOVA, $\mathrm{p}=0.76$ ).

\section{Total protein concentration}

Overall, diseased sponges had reduced total protein content compared to healthy sponges (ANOVA, $\mathrm{p}<0.0001$ for condition; Fig. 2a). Initial total protein concentrations were $157.8 \pm 3.81 \mathrm{\mu g} \mathrm{mg}^{-1}$ sponge tissue for healthy sponges and $126.8 \pm 4.02 \mu \mathrm{g} \mathrm{mg}^{-1}$ for diseased sponges. Protein content in diseased sponges did not change significantly over time; however, protein content in healthy sponges declined over time to $142.8 \mu \mathrm{g}$ protein $\mathrm{mg}^{-1}$ sponge tissue (ANOVA, $\mathrm{p}=0.042$ for time). Protein content was not significantly affected by nutrient dose (ANOVA, $p=0.67$ ), and there were no significant interactions or rack effects.

\section{Cyanobacterial symbiont densities}

Symbiont density ranged from 44 to 50 cells per viewing area $\left(2886 \mu^{2}\right)$. There was no significant effect of sponge condition (ANOVA, $p=0.63$; Fig. $2 b)$, nutrient dose $(p=0.75)$, or time $(p=0.081)$ on cyanobacterial symbiont densities. There was a significant amount of variation among racks $(\mathrm{p}=$ 0.016), which could reflect individual variation among sponges or the rack's position in the reef environment.
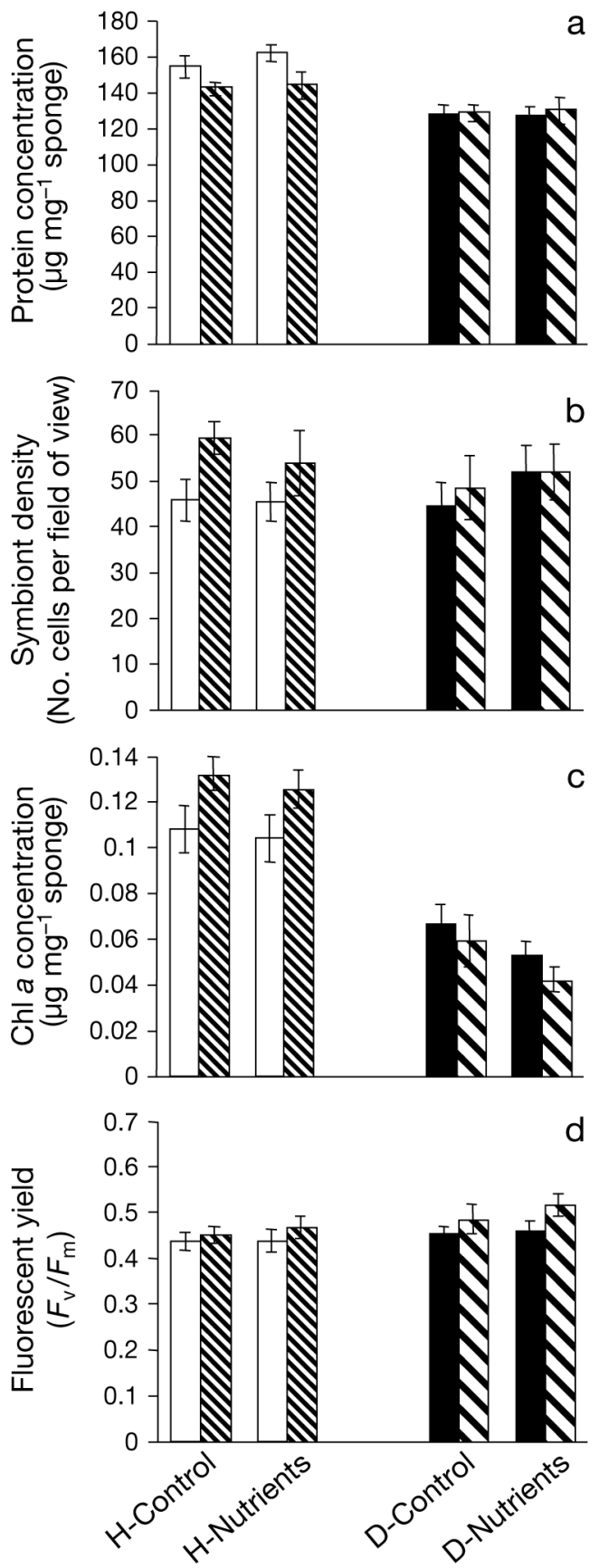

Fig. 2. Aplysina cauliformis. Mean $( \pm \mathrm{SE})$ initial (open/solid bars) and final (hatched bars) (a) protein concentration, (b) cyanobacterial symbiont density, (c) chlorophyll a concentration, and (d) dark-adapted fluorescent yield, in healthy $(\mathrm{H})$ and diseased (D) sponges exposed to control or nutrientenriched treatments $(n=12$ of each) 


\section{Chlorophyll a concentration}

Chl a concentrations were significantly higher in healthy sponges (ANOVA, $p<0.0001$ for condition; Fig. 2c), and there was a pronounced increase in chl a concentrations over time in the healthy sponges, but not diseased sponges $($ ANOVA, $\mathrm{p}=$ 0.0067 for time $\times$ condition interaction). Initially, chl $a$ concentrations in healthy sponges were $0.11 \pm$ $0.01 \mathrm{\mu g} \mathrm{mg}^{-1}$ sponge tissue in both treatments, and these increased to $0.13 \pm 0.0075 \mu \mathrm{g} \mathrm{mg}^{-1}$ in controls and $0.13 \pm 0.0085 \mu \mathrm{g} \mathrm{mg}^{-1}$ in the nutrient treatment by the end of the experiment. Chl a concentrations in diseased sponges decreased from $0.066 \pm 0.0088 \mu \mathrm{g}$ $\mathrm{mg}^{-1}$ sponge tissue to $0.059 \pm 0.011 \mu \mathrm{g} \mathrm{mg}^{-1}$ in the controls and from $0.059 \pm 0.0062 \mu \mathrm{g} \mathrm{mg}^{-1}$ to $0.041 \pm$ $0.0055 \mu \mathrm{g} \mathrm{mg}^{-1}$ in the nutrient treatment. There was no effect of nutrient dose (ANOVA, $p=0.17$; Fig. 2c), time $(p=0.31)$, or rack $(p=0.13)$ on chl a content. Overall, an increased density of cyanobacterial symbionts was not correlated with an increase in chl a content (regression, $\mathrm{p}>0.05$ ). Only the healthy control sponges exhibited a trend towards increasing chl a content with increasing symbiont density (regression, $\mathrm{p}=0.054$ ).

\section{Fluorescent yield}

Dark-adapted fluorescent yield increased significantly over time in all sponges (ANOVA, $p=0.047$ for time; Fig. 2d), and was unaffected by sponge condition or nutrient treatment (ANOVA, $p=0.087$ for condition, $p=0.44$ for dose). There was no effect of rack on fluorescent yield $(p=0.83)$. Fluorescent yield of healthy sponges increased from $0.432 \pm 0.019$ to $0.448 \pm 0.017$ in controls and from $0.435 \pm 0.025$ to $0.464 \pm 0.023$ in the nutrient treatment. Fluorescent yield of diseased sponges increased from $0.45 \pm 0.015$ to $0.481 \pm 0.031$ in controls and from $0.455 \pm 0.024$ to $0.513 \pm 0.023$ in the nutrient treatment.

\section{Bacterial community profiles}

Bacterial community profiles from tissues of healthy sponges and from diseased tissues of diseased sponges each exhibited tight clumping, indicating similar communities, whereas the communities from apparently healthy tissues of diseased sponges were not clumped, indicating greater variability (ANOSIM, p $=0.001$ for condition; Fig. 3). There was no effect of nutrient treatment on bacterial

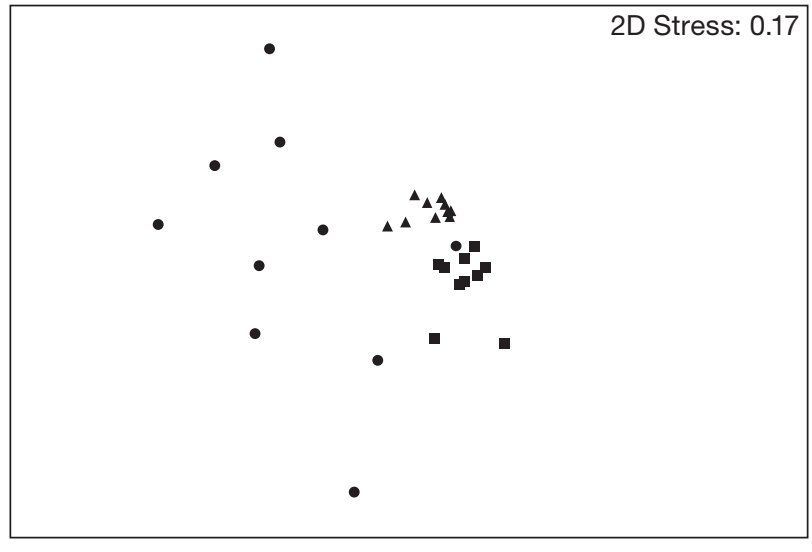

Fig. 3. Aplysina cauliformis. Non-metric multi-dimensional scaling plot showing similarities of bacterial communities

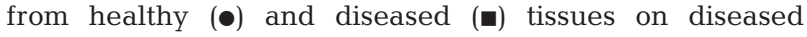
sponges, as compared to healthy sponges (ム). Bacterial communities from sponges in both the control and nutrient treatments did not differ and are therefore pooled within each sponge condition

community structure with either restriction endonuclease (ANOSIM, p > 0.05), so sponges from both control and nutrient treatments are pooled in Fig. 3, which shows only the data from HhaI digestions.

\section{DISCUSSION}

\section{Response to disease}

Coral reefs are simultaneously exposed to multiple natural and anthropogenic stressors, but the interactive effects of these impacts are rarely evaluated. In this study, the effects of both disease and nutrient enrichment on individuals of Aplysina cauliformis were investigated using a factorial experimental design. During this field-based experiment, healthy sponges gained weight $(8.65 \%$ of their starting mass), while diseased sponges lost $6 \%$ of their tissue mass, likely due to the rapid progression of ARBS bands that left behind expanding areas of necrosis (Fig. 1). Diseased sponges also had reduced total protein concentration (Fig. 2a), a measure of tissue nutritional content (Freeman \& Gleason 2010) and therefore, tissue condition. ARBS progressed rapidly, leaving behind increasing areas of necrotic tissue, over the course of the month-long experiment.

In contrast to changes in the host sponge tissue, disease did not affect the density of cyanobacterial symbionts in the healthy portions of diseased Aplysina cauliformis (Fig. 2b). Rützler (1988) suggested that pathogenesis in the mangrove sponge 
Geodia papyracea resulted from an inability to control proliferation of the sponge's cyanobacterial symbionts. In ARBS-affected A. cauliformis, Synechococcus spongiarum is absent from the red bands and necrotic regions, but symbiont density remains similar to healthy sponges in the remaining healthy portions of the diseased individuals. In spite of the similar densities of symbionts, chl a concentrations were significantly lower in the diseased sponges (Fig. 2c). However, the reduced chl a content of $A$. cauliformis did not have a measurable impact on fluorescent yield (Fig. 2d). The photosynthetic system in cyanobacteria is far more complex than in plants, algae, or dinoflagellates, relying not just on chlorophyll but on phycobilliproteins as well, and therefore measurements of chlorophyll fluorescence using PAM fluorometry must be interpreted with caution (Campbell et al. 1998). However, maximum potential quantum yield $\left(F_{\mathrm{v}} / F_{\mathrm{m}}\right)$ is still considered a useful parameter, particularly when the same individual is sampled over time (Campbell et al. 1998). PAM fluorometry has rarely been used an indicator of the condition of sponge photosymbiosis, although high densities of cyanobacteria were associated with high PAM fluorometry readings in a survey of sponges from Western Australia (Lemloh et al. 2009).

Sponges of the genus Aplysina host diverse microbial communities in addition to their photosymbiont populations (Friedrich et al. 2001, Hentschel et al. 2006, Hardoim et al. 2009). The sponge-associated bacterial communities in diseased tissues of $A$. cauliformis were distinct from those in tissues of healthy sponges (Fig. 3). In contrast, bacterial communities in healthy tissues from diseased sponges were highly variable and were not statistically different from those of either tissues of healthy sponges or diseased tissues, suggesting a transition from one type of community to another. Webster et al. (2008) also found localized differences in bacterial community composition in $A$. aerophoba affected by a different disease, and similar observations have been made in several species of corals affected by a diversity of diseases (Pantos et al. 2003, Bourne 2005, Sunagawa et al. 2009, Vega Thurber et al. 2009).

\section{Response to nutrients}

Disease had a much greater effect on Aplysina cauliformis than did nutrient enrichment, and there were few interactions. Using a similar nutrient enrichment treatment, Voss \& Richardson (2006) found that elevated concentrations of nutrients doubled the rate of progression of Black Band Disease in the coral Siderastrea siderea on reefs near LSI, and increased the rate of tissue loss. Likewise, Bruno et al. (2003) found that a 2 - to 5-fold increase in nutrient concentrations nearly doubled the rate of progression of Yellow Band Disease in Montastraea annularis in Puerto Rico. Proposed mechanisms for this increased rate of disease progression include enhancing the fitness or virulence of pathogens (Bruno et al. 2003), possibly through the release of pathogens from nutrient limitation (Voss \& Richardson 2006). In contrast to these studies on coral diseases, the rate of progression of ARBS was similar under enriched and ambient nutrient regimes (Fig. 1), suggesting that the ARBS pathogen(s) is not limited by nitrate or phosphate, or that diseased sponges are able to limit the rate of ARBS progression to some extent, possibly through up-regulation of chemical or other defenses.

The absence of nutrient effects, particularly related to measures of the sponge-cyanobacterial symbiosis, is surprising. Nutrient enrichment has been widely demonstrated to destabilize the host-symbiont relationship in corals, likely due to an increase in zooxanthellar population growth that out-competes the coral host for the $\mathrm{CO}_{2}$ necessary for calcification, or for nitrogen that would otherwise be translocated to the coral host (Dubinsky \& Stambler 1996, Szmant 2002, Fabricius 2005). As a result of the increased zooxanthellae population in corals, chl a content increases and gross primary production is often enhanced (Ferrier-Pagès et al. 2000, Fabricius 2005). In contrast to corals, few studies have considered the effects of nutrient enrichment on sponges, but this is surprising given the importance of sponges to nitrogen cycling in coral reef ecosystems (Fiore et al. 2010). Roberts et al. (2006) found that nutrient enrichment had no effect on sponge growth rate or chl a concentrations, suggesting that elevated nutrients did not enhance symbiont population growth. The few data available suggest that sponges may be more tolerant of nutrient stress than corals, possibly due to the presence of extracellular cyanobacteria instead of intracellular zooxanthellae as the dominant photosymbiont. The absence of nutrient effects observed in the present study may be due to the low nutrient doses used in our treatments (10 g versus $15 \mathrm{~g}$ in Voss \& Richardson 2006, and $30 \mathrm{~g}$ in Bruno et al. 2003). However, our nutrient treatment resulted in up to 4.8-fold enrichment of nitrate and up to 2.1-fold enrichment of phosphate over the course of $1 \mathrm{wk}$, and concentrations of both nutrients were greater than the proposed threshold values for shifts in relative dominance of coral reef functional groups (Lapointe 
1997). It appears that Aplysina cauliformis in this system may not be nutrient-limited. Even in the absence of anthropogenic nutrient enrichment, water motion due to surge and tidal flushing may still provide sufficient nutrient flux for these sponges and their symbionts (Miller et al. 1999), and Lapointe et al. (2004) previously reported higher nitrate concentrations on reefs near our study site.

\section{Changes over time}

Many of the endpoints in this study changed over time, independent of sponge condition or nutrient treatment. This is likely due to changes in seawater temperature and light regimes as summer progressed. This study was conducted from mid-June to mid-July, during which average daily seawater temperature at the study site increased from 27.6 to $29.4^{\circ} \mathrm{C}$, while solar irradiance and UV exposure also presumably increased. Cyanobacterial growth is facilitated by high light and temperature (van der Grinten et al. 2005). Elevated temperatures may also result in changes in sponge-associated bacterial communities (Lemoine et al. 2007). The rate of ARBS progression during this period was also much more rapid than previously reported (Olson et al. 2006), likely an effect of the elevated seawater temperature. Total protein content has also been reported to change seasonally in sponges (Elvin 1979), possibly due to reproductive stage. In addition, all sponges, regardless of their original orientation in the water column, were placed horizontally on racks in the field. For some individuals that were previously growing vertically, this may represent a change in orientation to light that could alter measures of the photosymbiosis (Fig. 2).

\section{Interactive effects}

There were few significant interactions between nutrients and disease in Aplysina cauliformis, indicating that nutrients and disease act on different aspects of sponge physiology. The only significant interaction effect was for chl a concentration, which increased over time in healthy sponges and decreased over time for diseased sponges (Fig. 2c). This, and the overall lower chl a concentration in the diseased sponges, suggests that ARBS inhibits the ability of the cyanobacterial symbionts to produce chl a. Likewise, the absence of a correlation between change in chl a concentration and change in cyanobacterial density for all treatments except the healthy controls, suggests that stress, either due to nutrients or disease, may inhibit chl a production.

The results observed in this study contrast with those from Gochfeld et al. (2007) in which Aplysina spp. sponges were virtually absent from a site of anthropogenic stress in Bocas del Toro, Panama, which included elevated nutrient concentrations as well as other stressors. This may be due to the already high levels of stress on these Panamanian reefs, where high rainfall and terrestrial runoff result in coral reef organisms that are already living near their stress tolerance points. A preliminary nutrient enrichment experiment on A. cauliformis in Panama resulted in a decline in fluorescent yield (D. J. Gochfeld \& J. B. Olson unpubl. data), a response that was not observed in the Bahamas, where sponges may be able to utilize additional low concentrations of exogenous nutrients. However, nutrient enrichment on coral reefs rarely occurs alone. Coastal development, agriculture, and sewage runoff also expose reefs to sedimentation, turbidity, and toxic pollutants, all of which may affect sponges and other reef organisms directly or indirectly. The impacts of multiple abiotic stressors and their interactions with biotic stressors such as pathogenesis need to be further elucidated on coral reefs.

Acknowledgements. We thank K. Pappas, M. de Johnson, C. Williams, X. Gao, L. O'Donahue, S. Lee, J. Weston, H. Kamel, M. Lesser, and M. Slattery for help in the lab and field. Funding was provided by collaborative NSF grant no. 0727996 to D.J.G., no. 0727833 to J.B.O., and no. 0726944 to R.W.T., and a NOAA/NIUST grant no. NA16RU1496 to D.J.G. Field support was provided by the Perry Institute of Marine Science/Caribbean Marine Research Center. All samples were collected under Bahamas Department of Fisheries permits.

\section{LITERATURE CITED}

Aronson RB, Macintyre IG, Wapnick CP, O'Neill MW (2004) Phase shifts, alternative states, and the unprecedented convergence of two reef systems. Ecology 85:1876-1891

Bell JJ (2008) The functional roles of marine sponges. Estuar Coast Shelf Sci 79:341-353

Bourne DG (2005) Microbiological assessment of a disease outbreak on corals at Magnetic Island (Great Barrier Reef, Australia). Coral Reefs 24:304-312

Bradford MM (1976) A rapid and sensitive method for the quantitation of microgram quantities of protein utilizing the principle of protein-dye binding. Anal Biochem 72: 248-254

$>$ Bruno JF, Petes LE, Harvell CD, Hettinger A (2003) Nutrient enrichment can increase the severity of coral diseases. Ecol Lett 6:1056-1061 
Campbell D, Hurry V, Clarke AK, Gustafsson P, Öquist G (1998) Chlorophyll fluorescence analysis of cyanobacterial photosynthesis and acclimation. Microbiol Mol Biol Rev 62:667-683

> Carpenter KE, Abrar M, Aeby G, Aronson RB and others (2008) One-third of reef-building corals face elevated extinction risk from climate change and local impacts. Science 321:560-563

Cervino JM, Winiarski-Cervino K, Polson SW, Goreau T, Smith GW (2006) Identification of bacteria associated with a disease affecting the marine sponge Ianthella basta in New Britain, Papua New Guinea. Mar Ecol Prog Ser 324:139-150

Cowart JD, Henkel TP, McMurray SE, Pawlik JR (2006) Sponge orange band (SOB): a pathogenic-like condition of the giant barrel sponge, Xestospongia muta. Coral Reefs 25:513

> Culman SW, Bukowski R, Gauch HG, Cadillo-Quiroz H, Buckley DH (2009) T-REX: software for the processing and analysis of T-RFLP data. BMC Bioinformatics 10:171

Diaz MC, Rützler K (2001) Sponges: an essential component of Caribbean coral reefs. Bull Mar Sci 69:535-546

> Dubinsky Z, Stambler N (1996) Marine pollution and coral reefs. Glob Change Biol 2:511-526

> Elvin DW (1979) The relationship of seasonal changes in the biochemical components to the reproductive behavior of the intertidal sponge, Haliclona permollis. Biol Bull (Woods Hole) 156:47-61

Erwin PM, Thacker RW (2007) Incidence and identity of photosynthetic symbionts in Caribbean coral reef sponge assemblages. J Mar Biol Assoc UK 87:1683-1692

- Erwin PM, Thacker RW (2008) Phototrophic nutrition and symbiont diversity of two Caribbean spongecyanobacteria symbioses. Mar Ecol Prog Ser 362:139-147

Fabricius KE (2005) Effects of terrestrial runoff on the ecology of corals and coral reefs: review and synthesis. Mar Pollut Bull 50:125-146

> Ferrier-Pagès C, Gattuso JP, Dallot S, Jaubert J (2000) Effect of nutrient enrichment on growth and photosynthesis of the zooxanthellate coral Stylophora pistillata. Coral Reefs 19:103-113

Fiore CL, Jarrett JK, Olson ND, Lesser MP (2010) Nitrogen fixation and nitrogen transformations in marine symbioses. Trends Microbiol 18:455-463

Freeman CJ, Gleason DF (2010) Chemical defenses, nutritional quality, and structural components in three sponge species: Ircinia felix, I. campana, and Aplysina fulva. Mar Biol 157:1083-1093

Freeman CJ, Thacker RW (2011) Complex interactions between marine sponges and their symbiotic microbial communities. Limnol Oceanogr 56:1577-1586

Friedrich AB, Fischer I, Proksch P, Hacker J, Hentschel U (2001) Temporal variation of the microbial community associated with the Mediterranean sponge Aplysina aerophoba. FEMS Microbiol Ecol 38:105-113

> Gaino E, Pronzato R, Corriero G, Buffa P (1992) Mortality of commercial sponges: incidence in two Mediterranean areas. Boll Zool 59:79-85

Galtsoff PS, Brown HH, Smith CL, Smith FGW (1939) Sponge mortality in the Bahamas. Nature 143:807-808

> Glibert PM, Heil CA, Hollander D, Revilla M, Hoare A, Alexander J, Murasko S (2004) Evidence for dissolved organic nitrogen and phosphorus uptake during a cyanobacterial bloom in Florida Bay. Mar Ecol Prog Ser 280:73-83
Gochfeld DJ, Schlöder C, Thacker RW (2007) Sponge community structure and disease prevalence on coral reefs in Bocas del Toro, Panama. In: Custódio MR, Lõbo-Hajdu G, Hajdu E, Muricy G (eds) Porifera research: biodiversity, innovation, and sustainability. Série Livros 28. Museu Nacional, Rio de Janeiro, p 335-343

> Hardoim CCP, Costa R, Arau'jo FV, Hajdu E and others (2009) Diversity of bacteria in the marine sponge Aplysina fulva in Brazilian coastal waters. Appl Environ Microbiol 75:3331-3343

Hentschel U, Usher KM, Taylor MW (2006) Marine sponges as microbial fermenters. FEMS Microbiol Ecol 55: $167-177$

Hoegh-Guldberg O, Mumby PJ, Hooten AJ, Steneck RS and others (2007) Coral reefs under rapid climate change and ocean acidification. Science 318:1737-1742

> Hughes TP (1994) Catastrophes, phase shifts, and largescale degradation of a Caribbean coral reef. Science 265: 1547-1551

Kaczmarsky L, Richardson LL (2011) Do elevated nutrients and organic carbon on Philippine reefs increase the prevalence of coral disease? Coral Reefs 30:253-257

Kaczmarsky LT, Draud M, Williams EH (2005) Is there a relationship between proximity to sewage effluent and the prevalence of coral disease? Caribb J Sci 41:124-137

Kuta KG, Richardson LL (2002) Ecological aspects of black band disease of corals: relationships between disease incidence and environmental factors. Coral Reefs 21: 393-398

Lapointe BE (1997) Nutrient thresholds for bottom-up control of macroalgal blooms on coral reefs in Jamaica and southeast Florida. Limnol Oceanogr 42:1119-1131

> Lapointe BE, Barile PJ, Yentsch CS, Littler MM, Littler DS, Kakuk B (2004) The relative importance of nutrient enrichment and herbivory on macroalgal communities near Norman's Pond Cay, Exuma Cays, Bahamas: a 'natural' enrichment experiment. J Exp Mar Biol Ecol 298:275-301

Lemloh ML, Fromont J, Brümmer F, Usher KM (2009) Diversity and abundance of photosynthetic sponges in temperate Western Australia. BMC Ecol 9:4

Lemoine N, Buell N, Hill A, Hill M (2007) Assessing the utility of sponge microbial symbiont communities as models to study global climate change: a case study with Halichondria bowerbanki. In: Custódio MR, Lõbo-Hajdu G, Hajdu E, Muricy G (eds) Porifera research: biodiversity, innovation, and sustainability. Série Livros 28. Museu Nacional, Rio de Janeiro

> Maldonado M, Sanchez-Tocino L, Navarro C (2010) Recurrent disease outbreaks in corneous demosponges of the genus Ircinia: epidemic incidence and defense mechanisms. Mar Biol 157:1577-1590

McCook LJ (1999) Macroalgae, nutrients and phase shifts on coral reefs: scientific issues and management consequences for the Great Barrier Reef. Coral Reefs 18: 357-367

Miller MW, Hay ME, Miller SL, Malone D, Sotka EE, Szmant AM (1999) Effects of nutrients versus herbivores on reef algae: a new method for manipulating nutrients on coral reefs. Limnol Oceanogr 44:1847-1861

> Murphy J, Riley JP (1962) A modified single solution method for determination of phosphate in natural waters. Anal Chim Acta 27:31-36

> Olson JB, Gochfeld DJ, Slattery M (2006) Aplysina red band syndrome: a new threat to Caribbean sponges. Dis Aquat Org 71:163-168 
Osborne CA, Rees GN, Bernstein Y, Janssen PH (2006) New threshold and confidence estimates for terminal restriction fragment length polymorphism analysis of complex bacterial communities. Appl Environ Microbiol 72: 1270-1278

Pantos O, Cooney RP, Le Tissier MDA, Barer MR, O'Donnell AG, Bythell JC (2003) The bacterial ecology of a plaguelike disease affecting the Caribbean coral Montastrea annularis. Environ Microbiol 5:370-382

Parsons TR, Maita Y, Lalli CM (1984) A manual of chemical and biological methods for seawater analysis. Pergamon Press, New York, NY

Porter JW, Dustan P, Jaap WC, Patterson KL and others (2001) Patterns of spread of coral disease in the Florida Keys. Hydrobiologia 460:1-24

Raymundo LJ, Couch CS, Bruckner AW, Harvell CD and others (2008) Coral disease handbook: guidelines for assessment, monitoring and management. Coral Reef Targeted Research \& Capacity Building for Management Program, St. Lucia

Roberts DE, Davis AR, Cummins SP (2006) Experimental manipulation of shade, silt, nutrients and salinity on the temperate reef sponge Cymbastela concentrica. Mar Ecol Prog Ser 307:143-154

Rodier M, Le Borgne R (2008) Population dynamics and environmental conditions affected Trichodesmium spp. (filamentous cyanobacteria) blooms in the south-west lagoon of New Caledonia. J Exp Mar Biol Ecol 358:20-32

Rosenberg E, Loya Y (2004) Coral health and disease. Springer, Berlin

Rützler K (1988) Mangrove sponge disease induced by cyanobacterial symbionts: failure of a primitive immune system? Dis Aquat Org 5:143-149

Rützler K (2004) Sponges on coral reefs: a community shaped by competitive cooperation. Boll Mus Ist Biol Univ Genova 68:85-148

Smith FGW (1941) Sponge disease in British Honduras, and its transmission by water currents. Ecology 22:415-421

Sunagawa S, DeSantis TZ, Piceno YM, Brodie EL and others (2009) Bacterial diversity and white plague diseaseassociated community changes in the Caribbean coral Montastraea faveolata. ISME J 3:512-521

Szmant AM (2002) Nutrient enrichment on coral reefs: Is it a

Editorial responsibility: Joseph Pawlik, Wilmington, North Carolina, USA major cause of coral reef decline? Estuaries 25:743-766

Thacker RW, Ginsburg DW, Paul VJ (2001) Effects of herbivore exclusion and nutrient enrichment on coral reef macroalgae and cyanobacteria. Coral Reefs 19:318-329

Vacelet J, Vacelet E, Gaino E, Gallissian MF (1994) Bacterial attack of spongin skeleton during the 1986-1990 Mediterranean sponge disease. In: van Soest RWM, van Kempen TMG, Braekman JC (eds) Sponges in time and space. Balkema, Rotterdam, p 355-362

$>$ Van der Grinten E, Janssen APHM, de Mutsert D, Barranguet C, Admiraal W (2005) Temperature- and lightdependent performance of the cyanobacterium Leptolyngbya foveolarum and the diatom Nitzschia perminuta in mixed biofilms. Hydrobiologia 548:267-278

> Vega Thurber R, Wilner-Hall D, Rodriguez-Mueller B, Desnues C and others (2009) Metagenomic analysis of stressed coral holobionts. Environ Microbiol 11: 2148-2163

Voss JD, Richardson LL (2006) Nutrient enrichment enhances black band disease progression in corals. Coral Reefs 25:569-576

Ward JR, Lafferty KD (2004) The elusive baselines of marine disease: Are diseases in ocean ecosystems increasing? PLoS Biology 2:e120

- Webster NS (2007) Sponge disease: a global threat? Environ Microbiol 9:1363-1375

- Webster NS, Negri AP, Webb RI, Hill RT (2002) A sponginboring $\alpha$-proteobacterium is the etiological agent of disease in the Great Barrier Reef sponge Rhopaloeides odorabile. Mar Ecol Prog Ser 232:305-309

Webster NS, Xavier JR, Freckelton M, Motti CA, Cobb R (2008) Shifts in microbial and chemical patterns within the marine sponge Aplysina aerophoba during a disease outbreak. Environ Microbiol 10:3366-3376

Wood ED, Armstrong FAJ, Richards FA (1967) Determination of nitrate in sea water by cadmium-copper reduction to nitrite. J Mar Biol Assoc UK 47:23-31

> Wulff JL (2006) A simple model of growth form-dependent recovery from disease in coral reef sponges, and implications for monitoring. Coral Reefs 25:419-426

- Wulff JL (2007) Disease prevalence and population density over time in three common Caribbean coral reef sponge species. J Mar Biol Assoc UK 87:1715-1720

Submitted: July 4, 2011; Accepted: March 8, 2012

Proofs received from author(s): May 21, 2012 